\title{
PERLINDUNGAN HUKUM TERHADAP ANAK PELAKU TINDAK PIDANA NARKOTIKA DALAM SISTEM PERADILAN PIDANA ANAK
}

\author{
Mochammad Anwar \\ anwar_mch@yahoo.com \\ DOI : https://doi.org/10.29313/sh.v17i1.5361
}

\begin{abstract}
ABSTRAK
Tindak pidana narkotika merupakan kejahatan yang bersifat luar biasa (extra ordinary crime) modus operandi cukup canggih dan terus mengalami perubahan untuk menghindari pelacakan aparat penegak hukum. Dewasa ini modus terbaru yang dilakukan adalah dengan melibatkan anak di bawah umur sebagai kurir atau pengantar narkoba ke tangan pengguna. Permasalahan yang menjadi titik perhatian adalah ketika anak tertangkap oleh petugas mereka langsung ditetapkan menjadi tersangka dan dimasukan ke dalam tahanan. Padahal anak mestinya ditempatkan sebagai korban dari perkembangan modus bandar besar dalam mendistribusikan narkoba. Fakta yang terjadi anak yang menjadi pelaku tindak pidana narkoba belum mendapatkan hak-haknya secara maksimal dalam sistem peradilan pidana anak.
\end{abstract}

Kata Kunci : Perlindungan Hukum, Anak Pelaku Tindak Pidana Narkotika.

ABSTRACT

Narcotic that is a crime extra ordinary (extra ordinary crime) modus operandy is quite advanced and continues to change in order to avoid tracking law enforcement officers. Today the latest mode is done by involving minors as couriers or the introduction of drugs into the hands of users. The problems that the focal point is when children caught by the officers they immediately set to dadder and put into custody. Though the child should be placed as a victim of a major city development mode in distributing drugs. The fact that there children who are perpetrators of criminal acts drugs have not gotten their rights to the fullest in the juvenile justice system.

Keywords: Legal Protection, Children Dadder Crime Narcotics. 


\section{PENDAHULUAN}

\section{A. Latar Belakang Masalah}

Salah satu persoalan yang perlu menjadi perhatian saat ini adalah ketika jaringan peredaran gelap narkotika baik nasional maupun internasional menggunakan modus operandi baru yaitu dengan melibatkan anak-anak sebagai kurir narkoba. Modus ini digunakan oleh para bandar untuk mengelabui aparat penegak hukum dan memperlancar distribusi narkoba sampai ke tangan pengguna.

Salah satu contoh kasus perdagangan narkoba yang melibatkan anak adalah kasus pengungkapan jaringan internasional yang diungkap BNN bekerjasama dengan Bea dan Cukai Bandara Halim Perdanakusuma. Pada bulan Agustus 2016 lalu petugas berhasil mengamankan 13 bungkus plastik berisi daun ganja seberat 256,8 gram, yang dikemas dalam plastik mainan lego. Modus mengedarkannya dilakukan dengan cara pemesanan secara online dan menjadikan anak-anak sebagai kurirnya. petugas mengamankan tiga orang tersangka yang berperan sebagai kurir dan masih berusia 16 tahun. ${ }^{1}$

Polisi sebagai gerbang terdepan proses penyaringan perkara pidana yang melaksanakan proses penyelidikan dan penyidikan terhadap pelaku tindak pidana narkotika dan psikotropika dalam hal ini merupakan instansi pertama dalam sistem peradilan pidana. Aparat penyidik polisi seringkali dianggap sebagai tonggak utama penegak hukum pidana pada umumnya dan hukum pidana anak pada khususnya, polisi melakukan penyelidikan dan penyidikan dalam rangka mengumpulkan bukti-bukti yang cukup untuk dapat dilanjutkan ke tahap peradilan selanjutnya. ${ }^{2}$

${ }^{1}$ Dedi Sonjaya, Penanggulanagan Tindak Pidana Narkotika, Jakarta, 2016, Hlm 26

${ }^{2}$ Satya Arinanto, Hak Asasi Manusia dalam Transisi Politik Indonesia, Jakarta, 2008, Hlm 81. 
Penyidik memiliki kewenangan yang menentukan apakah anak yang menjadi tersangka tindak pidana narkotika akan dilakukan penahanan atau tidak. Proses penahanan ini didasarkan pada Pasal 32 Undang-undang No 11 Tahun 2012 tentang Sistem Peradilan Pidana Anak bahwa:

(1). Penahanan terhadap Anak tidak boleh dilakukan dalam hal Anak memperoleh jaminan dari orang tua/Wali dan/atau lembaga bahwa Anak tidak akan melarikan diri, tidak akan menghilangkan atau merusak barang bukti, dan/atau tidak akan mengulangi tindak pidana.

(2). Penahanan terhadap Anak hanya dapat dilakukan dengan syarat sebagai berikut:

a. Anak telah berumur 14 (empat belas) tahun atau lebih; dan

b. diduga melakukan tindak pidana dengan ancaman pidana penjara 7 (tujuh) tahun atau lebih.

(3). Syarat penahanan sebagaimana dimaksud pada ayat (2) harus dinyatakan secara tegas dalam surat perintah penahanan.

(4). Selama Anak ditahan, kebutuhan jasmani, rohani, dan sosial Anak harus tetap dipenuhi.

(5). Untuk melindungi keamanan Anak, dapat dilakukan penempatan Anak di LPKS.

Sementara tindak pidana yang dilakukan oleh anak dalam peredaran narkoba kebanyakan melanggar ketentuan Pasal 133 ayat (1) dan (2) Undang-undang No 35 Tahun 2009 tentang Narkotika yang menegaskan bahwa:

(1). Setiap orang yang menyuruh, memberi atau menjanjikan sesuatu, memberikan kesempatan, menganjurkan, memberikan kemudahan, memaksa dengan ancaman, memaksa dengan kekerasan, melakukan tipu muslihat, atau membujuk anak yang belum cukup umur untuk melakukan tindak pidana sebagaimana dimaksud dalam Pasal 111, Pasal 112, Pasal 113, Pasal 114, Pasal 115, Pasal 116, Pasal 117, Pasal 118, Pasal 119, Pasal 120, Pasal 121, Pasal 122, Pasal 123, Pasal 124, Pasal 125, Pasal 126, dan Pasal 129 dipidana dengan pidana mati atau pidana penjara seumur hidup, atau pidana penjara paling singkat 5 (lima) tahun dan paling lama 20 (dua puluh) tahun dan pidana denda paling sedikit Rp2.000.000.000,00 (dua miliar rupiah) dan paling banyak Rp20.000.000.000,00 (dua puluh miliar rupiah). 
(2) Setiap orang yang menyuruh, memberi atau menjanjikan sesuatu, memberikan kesempatan, menganjurkan, memberikan kemudahan, memaksa dengan ancaman, memaksa dengan kekerasan, melakukan tipu muslihat, atau membujuk anak yang belum cukup umur untuk menggunakan Narkotika, dipidana dengan pidana penjara paling singkat 5 (lima) tahun dan paling lama 15 (lima belas) tahun dan pidana denda paling sedikit Rp1.000.000.000,00 (satu miliar rupiah) dan paling banyak Rp10.000.000.000,00 (sepuluh miliar rupiah).

Kondisi yang terjadi saat ini adalah anak-anak yang menjadi kurir mereka terbujuk oleh iming-iming bandar yang akan memberikan imbalan berupa uang yang cukup besar kepada anak sehingga mereka mau menjadi kurir. Perlu dipahami bahwa anak berbeda dengan orang dewasa pada saat mengambil keputusan untuk melakukan suatu perbuatan, sehingga dalam kondisi ini anak sepatutnya diposisikan sebagai korban bukan sebagai pelaku.

Fakta yang terjadi saat ini anak yang menjadi kurir dijadikan tersangka dan dimasukan ke dalam tahanan oleh penyidik untuk selanjutnya dilakukan pemeriksaan dalam proses peradilan pidana. Penempatan anak pada tahanan bukan suatu tindakan yang tepat meskipun didasarkan pada Undang-undang SPPA, karena penyidik harus memperhatikan aspek kemanfaatan dan dampak negatif yang dapat terjadi apabila anak ditempatkan dalam tahanan.

Pada saat anak tertangkap menjadi kurir narkoba mereka seharusnya bukan dipidanakan melainkan harus dibimbing dan dilindungi hak-haknya. Seharusnya penegak hukum mengejar bandar yang mengeksploitasi anak dalam peredaran narkoba. Penyelesaian perkara anak dalam jaringan narkoba mestinya diselesaikan secara diversi agar menghindarkan anak dari pemidanaan. Akan tetapi kenyataannya anak yang menjadi kurir ditetapkan menjadi tersangka dan diperiksa tanpa memperhatikan hak-haknya secara baik. Penetapan anak menjadi tersangka tidaklah salah namun yang perlu dicatat setelah penetapan tersangka maka penyidik harus benar-benar 
memperhatikan hak-haknya dan sebisa mungkin anak harus dihindarkan dari proses penahanan dan pemidanaan. ${ }^{3}$

Menahan dan mempidanakan anak yang menjadi kurir tidak akan membuat persoalan perdagangan narkotika menjadi hilang. Akan tetapi justru akan membahayakan hak-hak dan kepentingan anak, sekali anak masuk dalam sistem peradilan, maka pada saat itu ia akan selalu teringat dan berpotensi menimbulkan dampak traumatis. Lebih jauh lagi anak dapat menjadi perilaku kriminal yang lebih berbahaya di masa mendatang.

Melihat kenyataan inilah fungsi dan peran kepolisian dalam kedudukannya sebagai aparat yang berwenang melakukan penyelidikan dan penyidikan dituntut untuk menjalankan tugas dan kewajibannya seperti yang telah ditentukan dalam Undang-Undang No. 2 Tahun 2002 tentang Kepolisian Negara Republik Indonesia. Dalam rangka melaksanakan tugasnya sebagai gerbang utama proses peradilan pidana, penyidik polisi menanggung beban yang tidak ringan. Penyidik polisi harus benar-benar menjadi penyidik yang baik, dan juga penilaian yang baik. Penyidik polisi harus melakukan penyaringan-penyaringan terhadap arus perkara yang masuk. Pada dasarnya, tidak semua perkara pidana yang masuk dan diterima oleh penyidik polisi diteruskan ke tahapan peradilan selanjutnya. Penyidik polisi diberi kewenangan kebijakan diskresi untuk melanjutkan atau tidak perkara pidana ke tahap selanjutnya. ${ }^{4}$

\section{B. Identifikasi Masalah}

\footnotetext{
${ }^{3}$ Surjono dan Bony Daniel, Narkotika, Jakarta, 201, Hlm 72

${ }^{4}$ Lamintang, Dasar-dasar Hukum Pidana Indonesia, PT Citra Aditya Bhakti, Bandung, 1997, Hlm 46
} 
1. Bagaimana implementasi perlindungan hukum terhadap anak yang menjadi pelaku tindak pidana narkotika dihubungkan dengan Undangundang No 35 Tahun 2009 tentang Narkotika dan Undang-undang No 11 Tahun 2012 Tentang Sistem Peradilan Pidana Anak?

2. Apakah faktor yang menjadi penghambat perlindungan hukum bagi anak pelaku tindak pidana narkotika dalam sistem peradilan pidana?

\section{B. Metode Penelitian}

Metode penelitian dalam penulisan ini menggunakan pendekatan yuridis normatif karena menggunakan data sekunder di bidang hukum seperti Undang-Undang No 35 Tahun 2009 tentang Narkotika dan Undangundang No 11 Tahun 2012 Tentang Sistem Peradilan Pidana Anak, KUHP, buku, jurnal dan makalah-makalah. Teknik pengumpulan data menggunakan studi kepustakaan, sedangkan teknik analisis data menerapkan metode kualitatif.

\section{PEMBAHASAN}

A. Implementasi Perlindungan Hukum Terhadap Anak Pelaku Tindak Pidana Narkotika Dihubungkan Dengan Undang-undang No 35 Tahun 2009 tentang Narkotika dan Undang-undang No 11 Tahun 2012 Tentang Sistem Peradilan Pidana Anak

Perlindungan terhadap anak yang menjadi pelaku tindak pidana narkotika baik sebagai kurir atau pengantar barang kepada konsumen atau menjadi pengintai yang menjadi kaki tangan bandar atau pengedar dalam kacamata hukum tetaplah sama kedudukannya sebagai subyek yang berhak untuk memperoleh perlindungan secara khusus ketika anak tersebut ditangkap dan diproses dalam peradilan.

Salah satu kasus peredaran narkoba yang melibatkan anak di bawah umur pernah terjadi di Kecamatan Tallo-Pare-pare Sulawesi Selatan. Pada Agustus 2016 lalu Kepolisian Direktorat Reserse Narkoba menangkap anak berusia 13 tahun karena kedapatan mengedarkan narkoba jenis shabu-shabu dari tangan anak tersebut. Polisi menemukan narkoba dalam bentuk saset, 
satu buah handphone, serta ratusan ribu uang pecahan 20 ribu dan 50 ribu rupiah. Penangkapan ini merupakan pengembangan sindikat pengedar narkoba di kota Pare-pare. ${ }^{5}$

Peredaran narkoba dengan menggunakan anak sebagai kurir atau pengedar saat ini cukup marak di berbagai wilayah Indonesia khususnya di wilayah Sulawesi Selatan dan beberapa Provinsi di Pulau Jawa. Peredaran narkoba dengan melibatkan anak menjadi perhatian pihak Kepolisian karena perlu ditangani secara khusus sesuai dengan ketentuan peraturanperundang-undangan yang berlaku.

Apabila dianalisis secara normatif menjadi kurir atau pengantar narkoba yang dilakukan oleh anak adalah suatu tindak pidana yang diancam dengan pidana penjara dalam Undang-undang No 35 Tahun 2009 tentang Narkotika. Artinya perbuatan pidana yang dilakukan oleh anak sebagai kurir merupakan perbuatan yang dilarang dan diancam dengan sanksi pidana baik berupa pidana penjara atau denda sebagaimana ketentuan pidana dalam Pasal 111 s/d 147 Undang-undang Narkotika. Namun proses penanganan anak yang melakukan tindak pidana tidak diatur dalam Undang-undang No 35 Tahun 2009 melainkan diatur dalam Undang-undang No 11 Tahun 2012 tentang Sistem Peradilan Pidana Anak. Jadi perbuatan pidana yang dilakukan anak melanggar Undang-undang Narkotika, namun hukum acara mengenai peradilan anak diatur secara khusus dalam Undang-undang Sistem Peradilan Pidana Anak. Oleh karena itu penyidik dalam menangani anak yang menjadi kurir, pengintai atau posisi lain yang menjadi bagian dari distribusi narkoba harus berpedoman pada Undang-undang Sistem Peradilan Pidana Anak.

Sebagai seorang yang belum dewasa anak memiliki hak-hak apabila berhadapan dengan hukum. Seorang anak yang ditangkap dan dituduh

\footnotetext{
${ }^{5}$ http/tv.fajar.co.id. diakses tgl 30-01-2016. Pkl 11.00
} 
sebagai kurir narkoba meski mempertanggungjawabkan perbuatannya dihadapan hukum, namun perlu juga diimbangi dengan perlindungan hukum yang bersifat khusus.

Perlindungan khusus bagi anak yang berhadapan dengan hukum lebih rinci dijelaskan dalam Pasal 3 Undang-undang No 11 tahun 2012 tentang Sistem Peradilan Pidana Anak yang menegaskan bahwa:

Setiap Anak dalam proses peradilan pidana berhak:

a. diperlakukan secara manusiawi dengan memperhatikan kebutuhan sesuai dengan umurnya;

b. dipisahkan dari orang dewasa;

c. memperoleh bantuan hukum dan bantuan lain secara efektif;

d. melakukan kegiatan rekreasional;

e. bebas dari penyiksaan, penghukuman atau perlakuan lain yang kejam, tidak manusiawi, serta

f. merendahkan derajat dan martabatnya;

g. tidak dijatuhi pidana mati atau pidana seumur hidup;

h. tidak ditangkap, ditahan, atau dipenjara, kecuali sebagai upaya terakhir dan dalam waktu yang paling singkat;

i. memperoleh keadilan di muka pengadilan Anak yang objektif, tidak memihak, dan dalam sidang yang

j. tertutup untuk umum;

k. tidak dipublikasikan identitasnya;

1. memperoleh pendampingan orang tua/Wali dan orang yang dipercaya oleh Anak;

m. memperoleh advokasi sosial;

n. memperoleh kehidupan pribadi;

o. memperoleh aksesibilitas, terutama bagi anak cacat;

p. memperoleh pendidikan;

q. memperoleh pelayananan kesehatan; dan

r. memperoleh hak lain sesuai dengan ketentuan peraturan perundangundangan.

Menurut ketentuan di atas seorang anak yang melakukan tindak pidana dan diproses dalam peradilan anak memiliki hak-hak yang dijamin oleh Undang-undang Sistem Peradilan Pidana Anak. Salah satunya hak untuk tidak ditangkap, ditahan dan dipenjara kecuali sebagai upaya terakhir. Hak yang disebutkan dalam huruf Pasal 3 huruf(h) ini merupakan salah satu 
hak yang fundamental dan benar-benar diperhatikan oleh penyidik PPA. Seorang anak yang terlibat dalam jaringan narkoba tidak serta merta harus dilakukan penahanan apalagi digabungkan dengan orang dewasa. Apabila tidak ada kepentingan untuk menahan maka anak harus dikembalikan kepada orang tua dengan dilakukan pembinaan terlebih dahulu.

Menghindarkan anak dari proses penahanan merupakan upaya untuk melindungi anak dari stigma/cap negatif yang bisa diberikan kepada masyarakat kepada anak dan untuk menghindari lingkungan tahanan atau penjara yang tidak baik untuk kepentingan kepribadiannya. Oleh karena itu, di sini perlu adanya pemahaman penyidik PPA terhadap hak-hak anak dalam proses peradilan.

Upaya kepolisian dalam memberikan perlindungan hukum bagi anak yang menjadi kurir atau pengantar narkoba dapat dilakukan dengan cara diversi sebagaimana diamanatkan oleh Undang-undang Sistem Peradilan Pidana Anak. Dalam Pasal 6 Undang-undang No 11 Tahun 2012 tentang Sistem Peradilan Pidana Anak disebutkan bahwa diversi bertujuan:

a. mencapai perdamaian antara korban dan anak

b. menyelesaikan perkara anak diluar peradilan

c. menghindarkan anak dari perampasan kemerdekaan

d. mendorong masyarakat untuk berpartsipasi

e. menanamkan rasa tanggung jawab kepada anak.

Diversi terhadap anak diwajibkan dalam semua proses peradilan sebagaimana diatur dalam Pasal 9 Undang-undang No 11 Tahun 2012 Tentang Sistem Peradilan Pidana Anak yang menegaskan bahwa:

(1). Penyidik, Penuntut Umum, dan Hakim dalam melakukan Diversi harus mempertimbangkan:

a. kategori tindak pidana;

b. umur Anak;

c. hasil penelitian kemasyarakatan dari Bapas; dan

d. dukungan lingkungan keluarga dan masyarakat.

(2). Kesepakatan Diversi harus mendapatkan persetujuan korban dan/atau keluarga Anak Korban serta kesediaan Anak dan keluarganya, kecuali untuk: 
a. tindak pidana yang berupa pelanggaran;

b. tindak pidana ringan;

c. tindak pidana tanpa korban; atau

d. nilai kerugian korban tidak lebih dari nilai upah minimum provinsi setempat.

Apabila melihat ketentuan dalam Pasal 9 di atas dan dibandingkan dengan data anak yang menjadi tersangka tindak pidana narkoba yang disajikan dalam bab sebelumnya, dapat ditentukan bahwa anak-anak yang menjadi kurir adalah masih berusia belia sekitar 15-17 tahun atau masih di bawah umur. Artinya proses diversi harus dikedepankan daripada proses peradilan formal.

Konsep diversi adalah konsep untuk mengalihkan suatu kasus dari proses formal ke proses informal. Proses pengalihan ditujukan untuk memberikan perlindungan terhadap anak yang berkonflik dengan hukum. Beberapa kepolisian di Indonesia telah melakukan konsep diversi ini. Misalnya Kepolisian kota Bandung tengah dalam melakukan tugas dan fungsinya melakukan penyidikan terhadap anak yang diduga melakukan tindak pidana. Untuk memeberikan perlindungan hukum kepada anak, penyidik yang melakukan penyidikan adalan polisi wanita (Polwan) yang memiliki minat, perhatian, dedikasi dan memahami masalah anak. Penyidikan oleh polisi wanita dimaksudkan untuk memeriksa tersangka dalam suasana kekeluargaan. Penyidik perlu meminta pertimbangan atau saran dari pembimbing kemasyarakatan, ahli pendidikan, ahli kesehatan jiwa, dan sebagainya. Pemeriksaan anak pelaku tindak pidana dilakukan di sebuah ruangan khusus dan bersifat rahasia. ${ }^{6}$

${ }^{6}$ Lilik Mulyadi, Pengadilan Anak di Indonesia, Teori Praktik dan Permasalahannya, Mandar Maju, Bandung, 2005, Hlm 35 
Berdasarkan penelitian, aparat penegak hukum khususnya kepolisian masih melakukan penahanan terhadap anak yang menjadi tindak pidana narkoba. Hal ini dilakukan karena kepolisian sebagai aparat penegak hukum menganggap tindak pidana yang dilakukan oleh anak adalah tindak pidana yang diancam dengan tujuh (7) tahun penjara. Alasan demikian memang dibenarkan. Namun perlu dicatat bahwa anak menjadi kurir narkoba adalah perbuatan yang pertama kali mereka lakukan (bukan residiv) dan apabila dikaji lebih jauh mereka bukan bagian dari jaringan distribusi narkoba melainkan sekelompok anak yang dimanfaatkan tenaganya untuk membantu peredaran narkoba. Oleh karena itu sebenarnya posisi anak dalam kasus-kasus yang diungkap oleh Kepolisian dan BNN adalah sebagai korban bukan tersangka.

Apabila penegak hukum menemukan keterlibatan anak dalam peredaran narkoba yang harus dikejar adalah bandar besarnya bukan anak yang menjadi kurir mereka hanya dimanfaatkan dengan iming-iming dan tipu muslihat bandar besar, sehingga penegak hukum harus bisa lebih pandai dari pengedar narkoba.

Perlindungan bagi anak pelaku tindak pidana narkoba perlu diselesaikan melalui kebijakan diversi yang dilakukan dengan cara musyawarah dengan melibatkan anak dan orang tua/walinya, korban dan/atau orang tua walinya, pembimbing kemasyarakatan, dan pekerja sosial profesional berdasarkan pendakatan keadilan restoratif. Selanjutnya apabila diversi menghasilkan sebuah kesepakatan yang dilakukan oleh penyidik atas rekomendasi pembimbing kemasyarakatan dan hasil kesepakatan diversi dapat berbentuk, ${ }^{7}$ antara lain:

1. Perdamaian dengan atau tanpa kerugian

\footnotetext{
${ }^{7}$ Darwan Prints, Hukum Anak Indonesia, PT Citra Aditya, Bandung, 2003, Hlm 18
} 
2. Penyerahan kembali pada orang tua/wali

3. Keikutsertaan dalam pendidikan atau pelatihan di lembaga pendidikan atau LPSK paling lama tiga bulan

4. Pelayanan masyarakat.

Jika proses diversi tidak mencapai kesepakatan atau kesepakatan diversi tidak dilaksanakan, penyidik akan melanjutkan kasus pada proses peradilan pidana anak dan proses peradilan akan dilaksanakan sesuai peraturan perundang-undangan yang berlaku yaitu undang-undang No.11 Tahun 2012 tentang Sistem Peradilan Pidana Anak.

Institusi Kepolisian dan BNN sebagai gerbang utama dalam menangani anak dan remaja yang terlibat dalam jaringan narkoba di berbagai daerah di Indonesia menjadi penentu apakah seorang anak akan dilanjutkan ke proses peradilan atau tindakan informal lainnya. Penahanan dilakukan terhadap anak tetap berpedoman pada aturan hukum mengenai hak-hak anak yang tercantum dalam Undang-undang No 11 tahun 2012 tentang Sistem Peradilan Pidana Anak. Pembedaan tempat penahanan, pemenuhan fasilitas yang melindungi perkembangan anak, pendidikan, hobi, akses dengan keluarga, perlindungan hak profesi anak, perlakuan dari penyiksaan kekerasan fisik dan mental, serta proses peradilan yang singkat dan cepat. ${ }^{8}$

Penahanan yang dilakukan oleh polisi harus tetap memperhatikan hak-hak anak dan memberikan perlakuan yang berbeda seperti anak ditahan pada tempat yang khusus tahananan anak, dilakukan pemeriksaan dalam suasana kekeluargaan dan tidak adanya pembentakan ataupun pemukulan yang dilakukan terhadap anak. Saat penahanan diupayakan anak didampingi oleh orang tuanya atau Bapas.

Upaya penghindaran penahanan dilakukan untuk mengurangi akibat negatif yang lebih besar lagi. Tindakan untuk tidak menahan dikarenakan

${ }^{8}$ Nashriana, Perlindungan Hukum Pidana Bagi Anak di Indonesia, Rajawali Pers, Jakarta, 2011, Hlm 19 
menurut penilaian bahwa anak tersebut baru pertama kali melakukan tindak pidana dan masih dapat diperbaiki. Tindakan untuk penghindaran penahanan tersebut juga jika dihubungkan dengan ketentuan dalam Beijing Rules merupakan hak yang dimiliki oleh tersangka anak sebagaimana diatur dalam butir 13 the Beijing Rules, dijelaskan "Penahanan sebelum pengadilan hanya akan digunakan sebagai pilihan terakhir dan untuk jangka waktu yang sesingkat-singkatnya".

Tanggung jawab untuk memberikan perlindungan terhadap anak agar terhindar dari bisnis narkoba tidak hanya menjadi tanggung jawab pihak kepolisian namun juga menjadi tanggung jawab semua elemen masyarakat. Hal ini dicantumkan dalam Pasal 20 Undang-undang No 35 tahun 2014 tentang Perlindungan Anak yang menegaskan bahwa:

"Negara, pemerintah, masyarakat, keluarga, dan orang tua berkewajiban dan bertanggung jawab terhadap penyelenggaraan perlindungan anak".

Dalam kenyataan acap kali ditemukan fenomena keterlibatan anak dalam jaringan narkoba justru karena pengaruh atau minimal sebagai akibat dari kondisi sosial yang kurang menguntungkan bagi perkembangan mental anak/remaja. Di sisi lain, kondisi sosial yang sehat dapat diupayakan oleh masing-masing individu di dalam masyarakat atau dapat pula diciptakan oleh para pemimpin yang bertanggung jawab atas keamanan, ketentraman dan kedamaian dalam lingkungan hidup masyarakat. Terwujudnya kondisi ini seyogyanya diusahakan sedini mungkin sehingga segi-segi negatif tersebut tidak mengganggu atau meresahkan hidup masyarakat, terutama sekali tidak mengganggu perkembangan anak. ${ }^{9}$

${ }^{9}$ D.Y. Staa, Pokok-pokok Pelaksanaan Sidang Perkara Anak-anak di Pengadilan Negeri dalam daerah Hukum Pengadilan Negeri Jakarta, Binacipta, Bandung, 1979, Hlm 44 
Perlindungan hukum bagi anak yang menjadi pelaku tindak pidana narkoba sejatinya tidak menggunakan penahanan atau penjatuhan pidana. Pidana penjara tidak dapat memberikan jaminan bahwa anak yang masuk dalam lembaga pemasyarakatan anak akan menjadi baik. Upaya yang perlu dikedepankan oleh Kepolisian kepada anak adalah nasihat dan himbauan serta melibatkan peran serta orang tua dan masyarakat, penanggulangan tindak pidana narkotika yang melibatkan anak lebih tepat bila menggunakan sarana non penal karena melihat anak sebagai indivdu yang belum memiliki kecakapan fisik dan mental.

\section{B. Faktor Penghambat Perlindungan Hukum Bagi Anak Pelaku Tindak Pidana Narkotika Dalam Sistem Peradilan Pidana Anak}

Berdasarkan penelitian penyelesaian perkara anak-anak yang menjadi pelaku tindak pidana narkotika oleh penegak hukum, bahwa sebagian besar perkara anak dilimpahkan/dilanjutkan ke tahap penuntutan, disebabkan oleh kejahatan yang dilakukan oleh anak memberikan dampak besar terhadap situasi keamanan dan ketertiban masyarakat. ${ }^{10}$

Untuk melaksanakan perlindungan bagi anak yang berhadapan dengan hukum karena menjadi tersangka tindak pidana narkotika dalam sistem peradilan pidana anak. Meskipun telah ada Undang-undang No 11 Tahun 2012 Tentang Sistem Peradilan Pidana Anak yang menjadi acuan bagi penyidik dalam menangani anak. Namun dalam praktek masih ditemukan berbagai kendala yang menjadi hambatan dalam memberikan perlindungan terhadap anak. Kendala yang dimaksud antara lain:

\section{Faktor Masyarakat}

Selama ini masyarakat di Indonesia masih memiliki pandangan bahwa setiap orang yang melakukan kejahatan harus diberikan hukuman yang setimpal tidak terkecuali dengan anak. Seorang anak yang terlibat dalam jaringan narkoba dianggap sebagai kejahatan yang besar dan membahayakan bagi kehidupan masyarakat sehingga pelakunya harus

${ }^{10}$ Marlina, Peradilan Pidana Anak di Indonesia, Refika Aditama, Bandung, 2012, Hlm 27 
dihukum berat. Persepsi masyarakat yang demikian akan mempengaruhi proses peradilan pidana anak yang berjalan di tingkat penyidikan, penuntutan dan persidangan. Penegak hukum dituntut untuk menjatuhkan pemidanaan kepada anak agar tidak melakukan keresahan lagi di tengahtengah masyarakat.

Sampai sekarang masyarakat masih menganut paham pembalasan, dengan mencerca, menghinakan seseorang yang melakukan kejahatan. Persepsi demikian sangat terasa ketika penegak hukum telah transparan dalam menyelesaikan kasus anak dengan melibatkan keluarga dan tokoh masyarakat. Namun dalam beberapa kasus masyarakat tidak mendukung adanya proses perdamaian yang berlangsung melalui diversi, karena mereka berpandangan bahwa kenakalan yang dilakukan anak sudah melampaui batas kewajaran.

Pandangan masyarakat yang sedemikian rupa tentang kejahatan narkoba membuat anak sulit memperoleh hak-haknya dalam sistem peradilan pidana anak. Terkadang oknum-oknum masyarakat tertentu melakukan penekanan terhadap penegak hukum agar anak yang melakukan tindak pidana narkotika dihukum seberat-beratnya. Penekanan dari masyarakat merupakan faktor yang bersifat eksternal namun memberi pengaruh yang cukup kuat dalam proses penanganan anak dalam sistem peradilan.

\section{Faktor Penegak Hukum}

Sebagaimana teori legal system yang dikemukakan oleh Lawrence Meir Friedman bahwa berjalanya hukum dalam masyarakat dipengaruhi oleh tiga faktor yaitu Undang-undang (Good Legislation), Penegak Hukum (Legal Stucture) dan Budaya Hukum (Legal Culture). Secara praktikal perlindungan hukum bagi anak yang menjadi pelaku tindak pidana narkotika dipengaruhi oleh faktor penegak hukum (penyidik, penuntut umum dan hakim). Faktor penegak hukum ini dapat dibagi menjadi dua (1). Secara kualitas; (2). Secara kuantitas. 
Secara kualitas penegak hukum belum memahami secara keseluruhan mengenai penyelesaian kasus anak melalui proses peradilan khususnya dalam penerapan kebijakan diversi. Diversi memberikan makna yang luas terhadap jenis dan tindakan apa saja yang dapat disebut diversi. Setiap tindak pidana yang terjadi dan masuk dalam proses formal maka akan ditangani oleh aparat penegak hukum sampai mempunyai keputusan. Penerapan diversi dalam banyak praktek banyak disalahgunakan oleh penegak hukum baik di perkotaan maupun di berbagai daerah di Indonesia. Lemahnya kualitas integritas penegak hukum yang ada membuat proses penerapan diversi digunakan untuk menyelesaikan kasus melalui kesepakatan tanpa ada musyawarah dan mufakat yang semestinya melibatkan berbagai pihak. Praktek ini kemudian membuat kepercayaan masyarakat menurun terhadap proses peradilan yang ada dan berujung pada pengabaian hak-hak anak.

Sedangkan secara kuantitas penyidik untuk perkara anak yang ada tersebar di seluruh Polda, Polres dan Polsek belum sesuai dengan kebutuhan, serta belum optimalnya kualitas penyidik perkara anak baik dari segi kemampuan, keahlian maupun keterampilan dalam menangani perkara anak seperti masih banyak Penyidik PPA yang belum mendapat pelatihan khusus. Beban tugas dan tanggung jawab perkara yang ditangani baik secara kualitas maupun kuantitas tidak proporsional. Penyidik tidak saja memeriksa atau menangani satu perkara yang harus diselesaikan, akan tetapi penyidik dengan keterbatasan jumlah personel pada unit satuannya, dibebani dan ditugaskan untuk memeriksa dan menyelesaikan lebih dari satu perkara dengan kualifikasi perkara yang variasi (berat dan ringan).

\section{Faktor Sarana dan Prasarana RPK/PPA}

Faktor sarana dan prasarana menjadi kendala tersendiri dalam memberikan perlindungan khusus bagi anak yang menjadi pelaku tindak pidana narkotika, kendala yang muncul akibat faktor ini disebabkan karena belum adanya dukungan anggaran untuk membangun sarana prasarana yang memadai guna melaksanakan proses penyidikan perkara anak secara 
proporsional dan akuntabel seperti Ruang Pelayanan Khusus (RPK) masih banyak yang belum layak.

Sebagaimana diketahui bersama anak yang menjadi pelaku tindak pidana perlu mendapatkan perlakuan khusus baik dalam tingkat penyidikan, penuntutan dan pemeriksaan dihadapan persidangan. Pada tahap penyidikan anak mesti diperiksa di Ruang Pelayanan Khusus (RPK) atau saat ini dikenal dengan unit Perlindungan Perempuan dan Anak (PPA). Unit ini dibangun untuk menempatkan anak dan memeriksanya selama proses penyidikan.

Adanya ruang RPK atau PPA ini berfungsi untuk menghindarkan anak dari tahanan atau narapidana dewasa yang akan memberikan dampak psikologis yang buruk untuk perkembangan kepribadiannya. Untuk itu memerlukan suatu ruangan atau unit khusus yang diperuntukan bagi anak yang menjadi pelaku tindak pidana termasuk narkoba. Bagaimanapun posisi dan kedudukan mereka dalam peredaran narkoba anak tetaplah anak yang belum memiliki kematangan berfikir dan berhak atas segala hak yang dijamin oleh undang-undang dalam semua tahap pemeriksaan.

\section{Belum Adanya Aturan Pelaksana Diversi}

Aturan pelaksana dalam sebuah kebijakan hukum memiliki posisi yang sangat penting. Melalui aturan pelaksananya aparat penegak hukum mempunyai pedoman untuk melakukan suatu tindakan hukum demi kepentingan anak. Sejak lahirnya Undang-undang 11 Tahun 2012 Tentang Sistem Peradilan Pidana Anak telah memberikan terobosan untuk mengutamakan penyelesaian perkara anak melalui diversi. Namun sampai saat ini belum ada aturan pelaksana yang mengaturnya. Akibatnya aparat penegak hukum dalam melaksanakan diversi menggunakan pandangan pribadinya masing-masing, meskipun sudah ada di beberapa daerah yang mendasarkan pada kesepakatan bersama untuk kepentingan terbaik bagi anak.

Aturan pelaksana mengenai diversi mestinya dibuat mulai dari Peraturan Pemerintah sampai pada Peraturan Kapolri yang mewajibkan 
penyidik untuk mengedepankan proses diversi dalam penanganan anak yang berkonflik dengan hukum. Keberadaan aturan pelaksana ini penting untuk menghindari multitafsir dikalangan penegak hukum.

Pada kasus narkoba yang melibatkan anak sebagai pelakunya diversi merupakan kebijakan yang sangat penting untuk diaplikasikan dalam proses peradilan formal. Akan tetapi terkadang aparat masih ragu-ragu dalam menjalankannya. Hal ini karena tuntutan masyarakat, keluarga korban atau hal lain yang menjadi pertimbangan aparat. Penyidik juga cenderung khawatir dan takut dipersalahkan di kemudian hari jika pelaku mengulangi perbuatannya. Terlebih masyarakat juga masih pesimis dengan kebijakan diversi yang akan merugikan kepentingan pihak tertentu.

Penerbitkan aturan pelaksana mengenai diversi perlu diimbangi dengan komitmen penyidik PPA untuk memberikan perlindungan yang maksimal dan tanpa diskriminasi bagi anak pelaku tindak pidana narkoba agar terhindar dari proses penghukuman yang dapat berdampak negatif bagi pertumbuhan anak.

\section{PENUTUP}

\section{A. Simpulan}

1. Implementasi perlindungan hukum terhadap anak pelaku tindak pidana narkotika sejauh ini belum optimal, karena penyidik cenderung mengutamakan tindakan penahanan bagi anak pelaku tindak pidana narkotika yang berpotensi menimbulkan dampak negatif dan traumatis bagi anak, sehingga mengakibatkan anak belum memperoleh perlindungan hukum yang maksimal sesuai dengan Undang-undang No 11 Tahun 2012 tentang Sistem Peradilan Pidana Anak. Semestinya penahanan ditempatkan sebagai upaya terakhir dan mengedepankan kepentingan terbaik anak. Mengingat anak yang melakukan tindak pidana narkotika merupakan perbuatan yang pertama kali (bukan residiv), terlebih anak hanya dimanfaatkan (dieksploitasi) oleh para bandar untuk memperlancar peredaran gelap narkotika. 
2. Perlindungan hukum bagi anak pelaku tindak pidana narkotika dalam sistem peradilan pidana anak mengalami beberapa kendala yang menghambat proses pemberian perlindungan secara optimal. Kendala dimaksud antara lain: (a). Pandangan masyarakat terhadap pelaku tindak pidana narkoba masih menganut paham penghukuman (retributif) tidak terkecuali dengan anak. (b). Faktor kelemahan aparat penegak hukum baik secara kualitas maupun kuantitas. (c). Faktor minimnya sarana dan prasarana RPK atau unit PPA karena terbentur dengan terbatasnya anggaran. (d). Ketiadaan aturan pelaksana mengenai diversi.

\section{B. Saran}

1. Perlindungan hukum bagi anak yang terlibat dalam peredaran gelap narkotika disarankan agar diberikan perlindungan khusus melalui proses diversi secara ketat yang melibatkan orang tua anak, tokoh masyarakat, tokoh agama dan institusi terkait untuk mencapai kesepakatan yang bertujuan menghindarkan anak dari proses penahanan dan penghukuman serta memberikan nasihat dan pembinaan terhadap anak. Diversi akan memberikan efek yang jauh lebih bermanfaat daripada harus menghukum anak dengan pidana penjara.

2. Bagi pemerintah dan penegak hukum disarankan agar melakukan langkah-langkah sebagai berikut:

a. Melakukan pembenahan baik secara kualitas maupun kuantitas melalui pelatihan dan pendistribusian tugas secara proprosional yang mengedepankan keadilan restoratif untuk kepentingan terbaik bagi anak pelaku tindak pidana narkotika;

b. Melakukan perbaikan dan penambahan jumlah sarana dan prasarana unit-unit PPA yang ada di institusi Kepolisian melalui penambahan anggaran secara proporsional;

c. Membuat aturan pelaksana diversi untuk menjadi pedoman teknis penegak hukum dalam sistem peradilan pidana anak. 


\section{DAFTAR PUSTAKA}

\section{A. Buku}

Darwan Prints, Hukum Anak Indonesia, PT Citra Aditya, Bandung, 2003.

D.Y. Staa, Pokok-pokok Pelaksanaan Sidang Perkara Anak-anak di Pengadilan Negeri dalam daerah Hukum Pengadilan Negeri Jakarta, Binacipta, Bandung, 1979.

Lamintang, Dasar-dasar Hukum Pidana Indonesia, PT Citra Aditya Bhakti, Bandung, 1997.

Lilik Mulyadi, Pengadilan Anak di Indonesia, Teori Praktik dan Permasalahannya, Mandar Maju, Bandung, 2005.

Marlina, Peradilan Pidana Anak di Indonesia, Refika Aditama, Bandung, 2012.

Nashriana, Perlindungan Hukum Pidana Bagi Anak di Indonesia, Rajawali Pers, Jakarta, 2011.

Satya Arinanto, Hak Asasi Manusia dalam Transisi Politik Indonesia, Jakarta, 2008.

Sujono dan Bony Daniel, Komentar dan Pembahasan Undang-undang No 35 Tahun 2009 tentang Narkotika, Sinar Grafika, Jakarta, 2013.

\section{B. Peraturan Perundang-undangan}

Undang-undang Dasar 1945

Undang-undang No 1 Tahun 1946 Tentang Kitab Undang-undang Hukum Pidana

Undang-undang No 8 Tahun 1981 Tentang Kitab Undang-undang Hukum Acara Pidana

Undamg-undang No 35 Tahun 2009 Tentang Narkotika

Undang-undang No 11 Tahun 2012 Tentang Sistem Peradilan Pidana Anak

Undang-undang No 35 Tahun 2014 Tentang Perlindungan Anak

\section{Internet}


Dedi, Penandatanganan Peraturan Bersama, Paradigma Penanganan Pengguna Narkoba; Lebih Humanis.http://humas.bnn.go.id diakses. Tgl 31-07-2016

indosiar.com.Napi Kembangkan Bisnis Narkoba dari Balik Penjara, diakses tgl 29 Agustus 2016

tv.fajar.co.id. diakses tgl 30-01-2016. Pkl 11.00 